\title{
Evaluation of CSM-CERES-wheat in simulating wheat yield and its attributes with different sowing environments in Tarai region of Uttarakhand
}

\author{
R. K. Pal ${ }^{1 *}$, K. S. Rawat ${ }^{2}$, J. Singh ${ }^{3}$ and N.S. Murty ${ }^{4}$ \\ ${ }^{1 *}$ Punjab Agricultural University, Regional Research Station, Bathinda-151 001, INDIA \\ ${ }^{2}$ Centre for Remote Sensing and Geo-Informatics, Sathyabama University, Chennai-600119, INDIA \\ ${ }^{3}$ Department of Agricultural Physics, Indian Agriculture. Research Institute, New Delhi-110 016, INDIA \\ ${ }^{4}$ Department of Agrometeorology, G.B. Pant Uni. of Agri. \& Technol., Pantnagar-263 145, INDIA \\ *Corresponding author. E-mail: rkpal1985@gmail.com
}

Received: November 11, 2014; Revised received: April 29, 2015; Accepted: May 22, 2015

\begin{abstract}
Crop Environment Resource Synthesis (CSM-CERES)-Wheat model was used to simulate responses of two wheat varieties with various sowing environments. In this context, during the year 2007-08 and 2008-09, experiments on three sowing dates viz. November 20, December 15, and January 9 and two varieties (PBW-343 and $\mathrm{WH}-542$ ) with three replications were conducted at the Norman E. Borlaug Crop Research Centre of G.B. Pant University of Agriculture \& Technology, Pantnagar $\left(29^{\circ} \mathrm{N}, 79.29^{\circ} \mathrm{E}\right.$ with $243.80 \mathrm{~m}$ above msl). Soil, plant, management and climatic data were collected from the experimental field. The data of 2007-08 and 2008-09 were used for model calibration and validation, respectively. Results revealed that the for model outputs were in good agreement with their corresponding observed values with $20^{\text {th }}$ November sown crop than other sowings of crop in terms of phenological events, biomass accumulation and grain yields. However, variety PBW-343 showed close proximity between simulated and observed outcomes with all sowing dates. The percent root mean square error (\% RMSE) values ranged from $5.9-15.6 \%, 2.2-7.6 \%$ for days to attain anthesis and physiological maturity, respectively. Moreover, \%RMSE and $t$-value ranged from $5.7-12.2 \%(t=-4.5$ to 1.8$), 1.6-3.3 \%(t=-4.1$ to 4.5$)$ and $1.9-5.8 \%(t=-3.7$ to 1.5$)$ for product weight, vegetative weight and product harvest index, respectively. Inspite of that, model fails to simulate maximum leaf area index having \% RMSE from $53.2-62.9 \%$. These results indicate that CERES-Wheat model can be used as a tool to support decision-making for wheat production in Tarai region of Uttarakhand.
\end{abstract}

Keywords: CERES-Wheat, Sowing dates, Wheat varieties

\section{INTRODUCTION}

Wheat is the most widely cultivated food crop and ranks first in the world among the cereals both in respect of area $221.17 \mathrm{~m}$ ha and production $716.82 \mathrm{mt}$ during 2013-14 (USDA, 2014). In India, it is the second important staple food crop next to rice with projected area, production and productivity of $30.00 \mathrm{~m}$ ha, $93.51 \mathrm{mt}$ and $3.12 \mathrm{t} \mathrm{ha}^{-1}$, respectively during 2013 -14 (USDA, 2014). It is also an important crop in Tarai region of Uttarakhand having an area of $0.37 \mathrm{~m}$ ha, with a total production of $0.87 \mathrm{mt}$ and productivity of $2369 \mathrm{~kg} \mathrm{ha}^{-1}$ (DAC, 2012). This winter golden grain cereal is a major contributor to the food security and provides more than 50 per cent calories to the people who are dependent on this staple food crop. The wheat production in the country is highly variable due to inter seasonal weather variability. The demand of wheat has been projected to be to $109 \mathrm{mt}$ by 2020 which needs sincere efforts to mitigate the effect of climatic aberrations (Datt et al., 2009).

Research as well as technological innovations in the fields of biological, physical, and chemical science which is directly or indirectly linked with agricultural production system (Bannayan et al., 2007; Andarzian et al., 2008), can improve understanding and management of the agricultural system in a holistic way by using crop simulation models. The performance of different varieties with various sowing environments can be simulated through crop models (Ghaffari et al., 2001, Bannayan et al., 2003, Heng et al., 2007 and Bassu et al., 2009).

The Decision Support System for Agrotechnology Transfer (DSSAT) is a wide-ranging decision support system (Hoogenboom et al., 2010) which consists of the Cropping System Model-Crop Environment Resource Synthesis (CSM-CERES)-Wheat (Ritchie et al., 1998), that provides validation of crop model outputs and allow users to compare simulated result with observed consequences. Validation of crop dynamic model for any crop and any area will be greater applicable to predict the crop growth parameters as well as yield components in advance which are important for planning as well as management.

CSM-CERES-wheat is broadly used as a technological 
tool in favor of strategic decision-making (Sarkar and Kar, 2006), moreover, it can be used for dryland as well as irrigated conditions to simulate the growth and development of wheat (Jones et al., 2003, Nain and Kersebaum, 2007 and Hoogenboom et al., 2010). The model has been evaluated and applied in favour of tropical (Timsina et al., 1995), subtropical (Hundal and Kaur, 1997 and Heng et al., 2000) as well as temperate conditions in Asia (Timsina and Humphreys, 2006 and Zhang et al., 2013), in order to provide improved knowledge and information of agricultural system. With these crop models, it became possible to simulate a living plant through the mathematical and conceptual relationship which governs its growth in the Soil-Water-Plant-Atmosphere Continuum.

The present study was made to evaluate the performance of the CSM-CERES-Wheat model to simulate growth, development, and yield of wheat as well as application of CSM-CERES-Wheat model in order to determine suitable sowing environment on wheat yield under irrigated conditions in Tarai region of Uttarakhand.

\section{MATERIALS AND METHODS}

Study area: Ground truth data were recorded from the experiments, conducted at the Norman Ernest Borlaug Crop Research Centre of Govind Ballabh Pant University of Agriculture \& Technology, Pantnagar $\left(29^{\circ} \mathrm{N}, 79.3^{\circ} \mathrm{E}\right.$ and $243.8 \mathrm{~m}$ above $\left.\mathrm{msl}\right)$ Uttarakhand with two wheat varieties viz. PBW-343 and WH-542 and three sowing environments i.e. $20^{\text {th }}$ November, $15^{\text {th }}$ December and $09^{\text {th }}$ January during 2007-08 and 2008-09). These cultivars were selected as they were recommended for this region and are still widely cultivated. The number of days to attain anthesis and physiological maturity were determined from randomly selected five plants in all the plots visually by the number of days taken from the sowing date to attain anthesis and physiological maturity. For grain and straw yield, plants in net plot were threshed separately with $12-14 \%$ moisture content that was recorded in $\mathrm{kg} \mathrm{plot}^{-1}$ and finally expressed in $\mathrm{kg} \mathrm{ha}^{-1}$. The detail of soil information used for CERES-wheat model and climatic conditions of the experimental site have been shown by Pal et al. (2012).

Models used: In the present study, we used CERES (Crop Environment Resource Synthesis)-wheat Cropping System Model (CSM) for simulation of wheat crop characters in terms of number of days to attain anthesis \& physiological maturity, product weight, vegetative weight and product harvest index (HI). In this context, genotypic coefficients for the wheat varieties i.e. PBW-343 and WH-542 were derived (Table 1) with the help of GENCALC software (DSSAT) from the experimental data of 2007-08 by using data sets of three treatments $\left(20^{\text {th }}\right.$ November, $15^{\text {th }}$ December and $09^{\text {th }}$ January sowings) and independent data sets viz. dates of sowing, anthesis \& physiological maturity, above ground biomass, yield \& its attributing characters. Initially, GENCALC determine the values of phenological coefficients, (PHINT, P1V, P1D and P5), thereafter, values of the coefficients for growth and grain development (G1, G2 and G3) in order to attain the best possible match between predicted and observed data for the selected phenotypic and yield components. The CERES-wheat model was well calibrated based on experimental data of 2007-08 and validated using 2008-09 field trail data with the help of genotypic coefficients of wheat for varieties PBW-343 and WH-542 (Table 1) in the climatic conditions of Tarai region of Uttarakhand.

Statistical analysis: Percent root mean square error (\% RMSE) and t-Test analysis was carried out to examine the magnitude of relationship between simulated and observed parameters of wheat varieties with different sowing environments, moreover, the level of significance was checked at $5 \%$ and $1 \%$ of probability in terms of dates of sowing (degrees of freedom: 3) and varieties (degrees of freedom: 5).

\section{RESULTS AND DISCUSSION}

Weather conditions during study period: The average minimum temperatures recorded between 8.7 to $10.7^{\circ} \mathrm{C}$ and 10.2 to $11.7^{\circ} \mathrm{C}$, while, average maximum temperature were found to be between 23.8 to $26.4^{\circ} \mathrm{C}$ and 25.6 to $28.5^{\circ} \mathrm{C}$ in $2007-08$ (Fig. 1a) and 2008-09 (Fig. 1b), respectively. On the other hand, mean air temperature ranged $16.3-18.6^{\circ} \mathrm{C}$ and 17.9 - $20.1^{\circ} \mathrm{C}$ in the year 2007-08 and 2008-09, respectively. During the study period, average relative humidity ranged 61.7 to $66.0 \%$ and 61.7 to $67.5 \%$ in 2007-08 and 2008-09, respectively. Among sowing dates, total $27.4 \mathrm{~mm}$ rainfall was recorded in 2007-08 and $35.6-38.0 \mathrm{~mm}$ in $2008-09$, however, average bright sunshine hours was recorded between $6.2-7.0$ and $6.7-7.8$ in the year 2007-008 and 2008-09, respectively.

Timely sown wheat crop (20 November) with an average seasonal air temperature of $16.3^{\circ} \mathrm{C}$ produced highest yield of $4580.3 \mathrm{~kg} \mathrm{ha}^{-1}$ in 2007-08, while, it was $4080.3 \mathrm{~kg} \mathrm{ha}^{-1}$ in 2008-09 with an average seasonal air temperature of $17.9^{\circ} \mathrm{C}$. By means of every 25 days delay in sowings with an increase in average seasonal air temperature of $0.9-1.4^{\circ} \mathrm{C}$, yield reduced by 13 to $29.0 \%$ in both the years (Pal et al., 2013).

Observed vs. simulated days to attain anthesis and physiological maturity (DAS): It is revealed from the data, that days taken to anthesis ranged between 81 to 90 and 69 to 89 ; however, days to attain physiological maturity ranged 106 to 123 and 97 to 122 for observed and simulated data, respectively (Figs. 2 and 3 ).

The crop sown on $20^{\text {th }}$ November showed close proximity with the simulated anthesis values $(\mathrm{t}=-2.7$; $\% \mathrm{RMSE}=5.9)$ as well as physiological maturity $(\mathrm{t}=-$ $3.2 ; \% \mathrm{RMSE}=2.2$ ) values followed by rest of the sowing dates. Mitchell (1996) has also reported a close 
Table 1. Genetic coefficients fitted for wheat crop cultivar PBW-343 and WH-542.

\begin{tabular}{|c|c|c|c|}
\hline \multirow{2}{*}{ Crop file } & \multirow{2}{*}{ Parameter } & \multicolumn{2}{|c|}{ Calibrated value } \\
\hline & & PBW-343 & WH-542 \\
\hline \multirow[t]{8}{*}{ Species } & PEG & 10 & 10 \\
\hline & PECM & 10 & 10 \\
\hline & P1DT & 20 & 20 \\
\hline & P1VT & 50 & 50 \\
\hline & $\mathrm{P} 2(1)$ & 80 & 80 \\
\hline & $\mathrm{P} 4(1)$ & 0.25 & 0.25 \\
\hline & $\mathrm{P} 4(2)$ & 0.10 & 0.10 \\
\hline & PDUR6 & 100 & 100 \\
\hline \multirow[t]{7}{*}{ Ecotype } & $\mathrm{P} 1$ & 200 & 200 \\
\hline & $\mathrm{P} 2$ & 200 & 200 \\
\hline & P3 & 200 & 200 \\
\hline & $\mathrm{P} 4$ & 200 & 200 \\
\hline & KCAN & 0.85 & 0.85 \\
\hline & PARUV & 2.8 & 2.8 \\
\hline & PARUR & 2.8 & 2.8 \\
\hline \multirow[t]{7}{*}{ Genotype } & P1V & 0 & 0 \\
\hline & P1D & 92 & 91 \\
\hline & P5 & 560 & 557 \\
\hline & G1 & 22 & 23 \\
\hline & $\mathrm{G} 2$ & 43 & 43 \\
\hline & G3 & 2.3 & 2.9 \\
\hline & PHINT & 95 & 88 \\
\hline
\end{tabular}

Abbreviation: PEG: Germination phase duration (Hydrothermal units); PECM: Emergence phase duration (Thermal units per cm depth); P1DT: Photoperiod threshold (h above which no effect); P1VT: Vernalization threshold (d; only for determining response); P2(1): Duration terminal spikelet to jointing (DU); P4(1): Duration end ear growth to anthesis (frP4); P4(2): Duration anthesis to end anthesis (frP4); PDUR6: Phase duration 6 (post physio.maturity $\left({ }^{\circ} \mathrm{C} . \mathrm{d}\right.$ ); P1: Duration of phase end juvenile to terminal spikelet (GDD, Growing Degree Days); P2: Duration of phase terminal spikelet to end leaf growth (GDD); P3: Duration of phase end leaf growth to end spike growth (GDD); P4: Duration of phase end spike growth to end grain fill lag (GDD); KCAN: PAR extinction coefficient (\#); PARUV: PAR conversion to dry matter ratio before the last leaf stage $\left(\mathrm{g} \mathrm{MJ}^{-1}\right)$; PARUR: PAR conversion to dry matter ratio after the last leaf stage ( $\mathrm{g}$ $\mathrm{MJ}^{-1}$ ); P1V: Days at optimum vernalizating temperature required to complete vernalization; P1D: Percentage reduction in development rate in a photoperiod $10 \mathrm{~h}$ shorter than the optimum relative that optimum; P5: Grain filling (excluding lag) period duration (GDD); G1: Kernel number per unit canopy weight at anthesis $\left(\mathrm{g}^{-1}\right)$; G2: Standard kernel size under optimum condition (mg); G3: Standard non-stressed dry weight (total, including grain) of a single tiller at maturity (g); PHINT: Phyllochron interval (GDD) agreement between observed and predicted days to achieve anthesis and physiological maturity. Variety PBW-343 possesses more accuracy $(\mathrm{t}=-3.5 ; \%$ $\mathrm{RMSE}=9.6)$ than $\mathrm{WH}-542(\mathrm{t}=-3.7 ; \% \mathrm{RMSE}=10.7)$ for anthesis, and also similar trends was found in respect of physiological maturity (Table 2).

Model underestimated the days taken to anthesis and physiological maturity among all the dates of sowing and varieties. Number of days to attain anthesis and physiological maturity were found to be decreased as the sowings were delayed (Table 2). Reduction in days to attain anthesis and maturity of wheat crop with delay in sowing has also been reported by Kour et al. (2010).

Observed vs. simulated product weight and vegetative weight $\left(\mathrm{kg} \mathrm{ha}^{-1}\right)$ : The product weight ranges between 3070 to $4442 \mathrm{~kg} \mathrm{ha}^{-1}$ and 3256 to $4255 \mathrm{~kg} \mathrm{ha}^{-1}$, however, vegetative weight ranged 3994 to $5221 \mathrm{~kg}$ ha ${ }^{-1}$ and 4162 to $5171 \mathrm{~kg} \mathrm{ha}^{-1}$ for observed and simulated data, respectively (Figs. 4 and 5).

The model estimated product weight was very close to the observed values with $20^{\text {th }}$ November sowing $(\mathrm{t}=-4.5 ; \% \mathrm{RMSE}=5.7)$ than crop sown on December $15^{\text {th }} \quad(\mathrm{t}=1.8 ; \% \mathrm{RMSE}=8.9)$, while, the difference between observed and simulated values was found to be large in case of $09^{\text {th }}$ January sowing $(\mathrm{t}=1.8 ; \%$

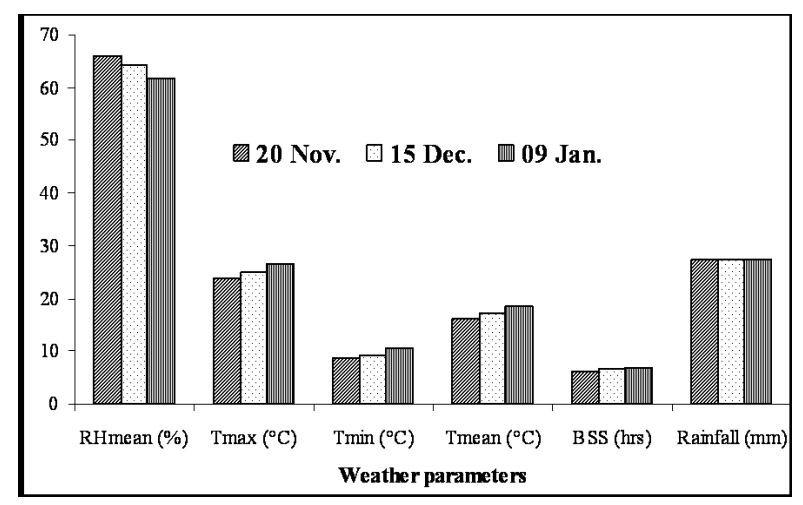

Fig. 1a. Average weather data of various parameters during Rabi season of 2007-08 of Pantnagar (experimental site) agro-meteorological observatory.

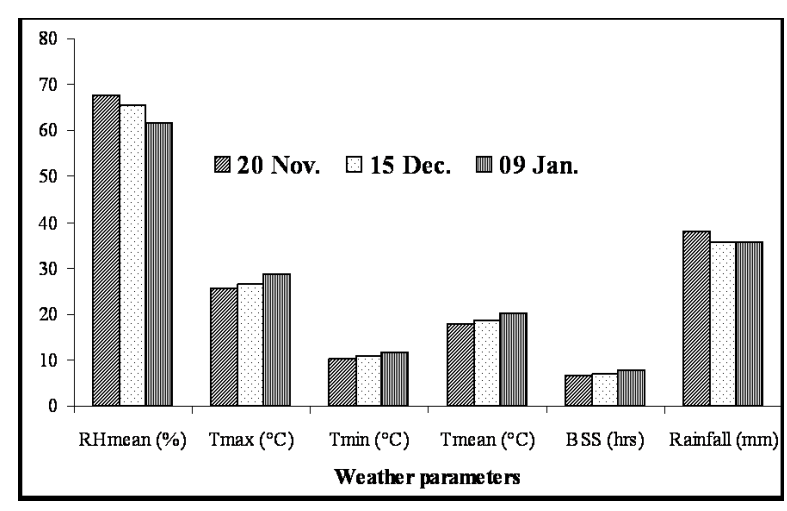

Fig. 1b. Average weather data of various parameters during Rabi season of 2008-09 of Pantnagar (experimental site) agro-meteorological observatory. 
Table 2. Statistics between simulated and observed wheat crop components.

\begin{tabular}{|c|c|c|c|c|c|}
\hline Phenophages & PBW-343 & WH-542 & Nov. 20 & Dec. 15 & Jan. 09 \\
\hline \multicolumn{6}{|c|}{ t-Test } \\
\hline Days to attain anthesis (DAS) & $-3.5 * *$ & $-3.7 * *$ & $-2.7 *$ & $-4.6 * *$ & $-23.7 * *$ \\
\hline Days to attain physiological maturity (DAS) & $-3.1 *$ & $-4.2 * *$ & $-3.2 *$ & $-4.5 *$ & $-12.0 * *$ \\
\hline Maximum Leaf Area Index & $-10.2 * *$ & $-10.7 * *$ & $-13.8 * *$ & $-21.5 * *$ & $-17.4 * *$ \\
\hline Product weight $\left(\mathrm{kg} \mathrm{ha}^{-1}\right)$ & -0.2 & 1.2 & $-4.5 * *$ & 1.8 & 1.8 \\
\hline Vegetative weight $\left(\mathrm{kg} \mathrm{ha}^{-1}\right)$ & 1 & 1.1 & $-4.1 *$ & $4.3^{*}$ & $4.5^{*}$ \\
\hline Product Harvest Index & -0.3 & 1.4 & $-3.7^{*}$ & 1.5 & 1.2 \\
\hline \multicolumn{6}{|c|}{ \%RMSE } \\
\hline Days to attain anthesis (DAS) & 9.6 & 10.7 & 5.9 & 6.9 & 15.6 \\
\hline Days to attain physiological maturity (DAS) & 4.1 & 5.3 & 2.2 & 3.4 & 7.6 \\
\hline Maximum Leaf Area Index & 53.2 & 62.9 & 59.9 & 56.7 & 53.8 \\
\hline Product weight $\left(\mathrm{kg} \mathrm{ha}^{-1}\right)$ & 5.8 & 11 & 5.7 & 8.9 & 12.2 \\
\hline Vegetative weight $\left(\mathrm{kg} \mathrm{ha}^{-1}\right)$ & 1.6 & 2.9 & 1.6 & 2 & 3.3 \\
\hline Product Harvest Index & 3.1 & 5 & 1.9 & 3.9 & 5.8 \\
\hline
\end{tabular}

$\%$ RMSE $=$ percent root mean square error, ${ }^{*}$ Significant at $0.05 P$ and $* *$ Significant at $0.01 P$

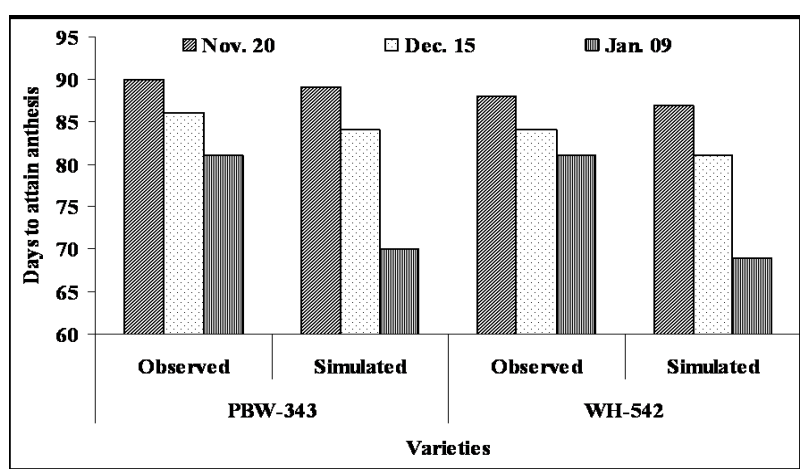

Fig. 2. Comparison between measured and simulated values for days taken to anthesis (DAS) at different dates of sowing and varieties of wheat (Mean of 2007-08 and 2008-09).

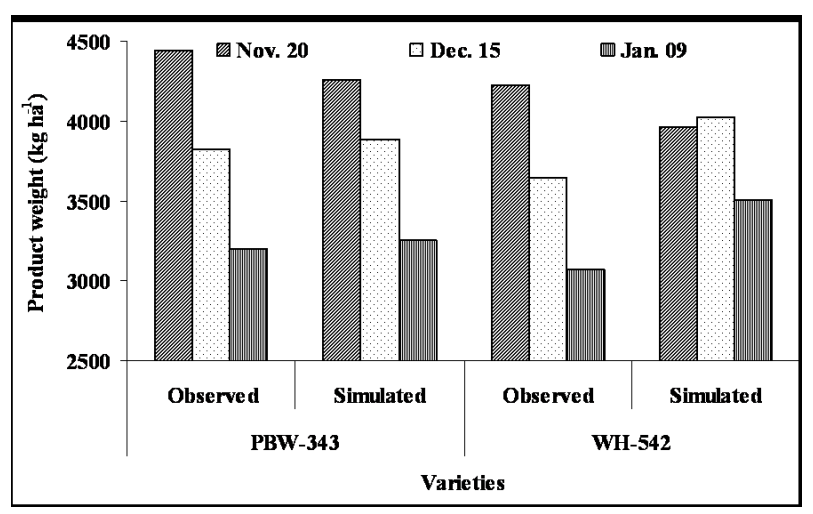

Fig. 4. Comparison between measured and simulated values for product weight $\left(\mathrm{kg} \mathrm{ha}^{-1}\right)$ at different dates of sowing and varieties of wheat (Mean of 2007-08 and 2008-09).

RMSE=12.2). On the other hand, for vegetative weight, less \%RMSE was found with early sowing

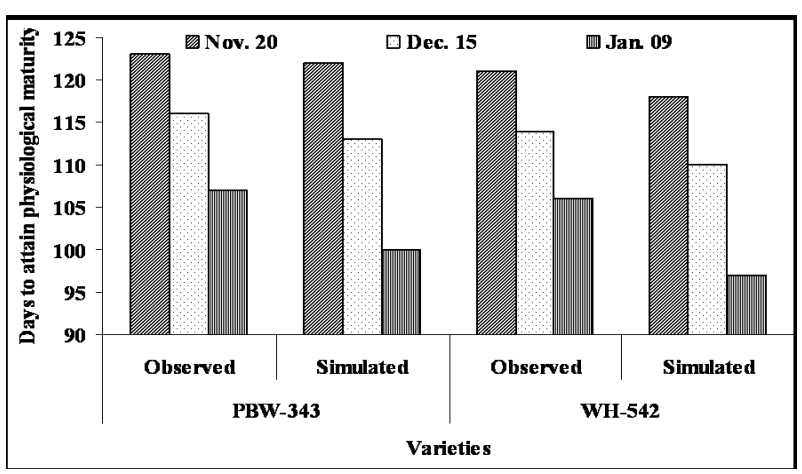

Fig. 3. Comparison between measured and simulated values for physiological maturity (DAS) at different dates of sowing and varieties of wheat (Mean of 2007-08 and 2008-09).

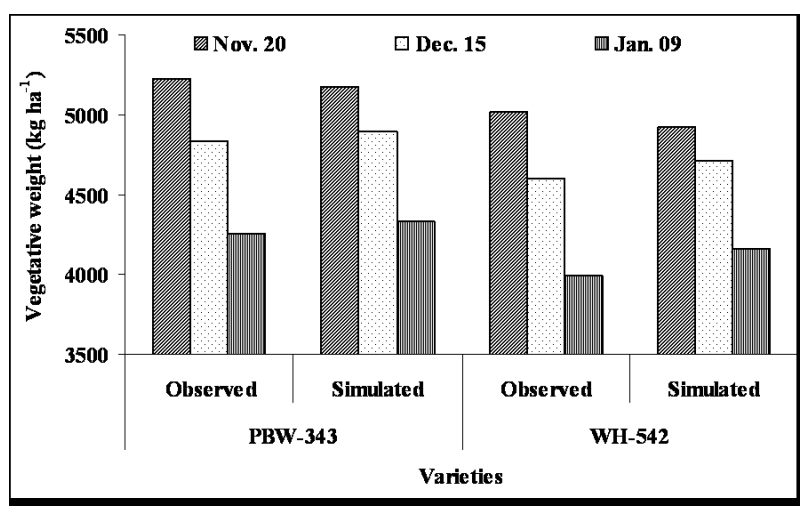

Fig. 5. Comparison between measured and simulated values for vegetative weight $\left(\mathrm{kg} \mathrm{ha}^{-1}\right)$ at different dates of sowing and varieties of wheat (Mean of 2007-08 and 2008-09).

(1.6) than mid (2.0) and late sown crop (3.3). In case of product weight, the performance of the model was 


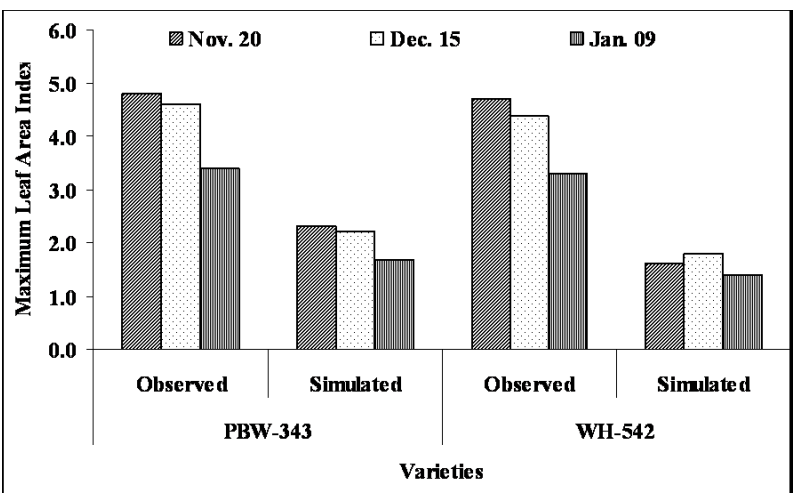

Fig. 6. Comparison between measured and simulated values for maximum Leaf Area Index at different dates of sowing and varieties of wheat (Mean of 2007-08 and 2008-09).

good for variety PBW-343 ( $\mathrm{t}=-0.2 ; \% \mathrm{RMSE}=5.8)$ compared to that of variety WH-542 $(\mathrm{t}=1.2 ; \%$ RMSE $=11.0$ ), however, similar circumstances was also observed with vegetative weight (Table 2). Nain et al. (2002) also reported that the model could very well simulate the crop yields (RMSE $<20 \%$ ).

Model underestimated the product weight with sowing done on $20^{\text {th }}$ November in both the years (Ouda et al., 2005; Patel et al., 2010) whereas it overestimated for the rest of the sowing dates (Dhaliwal et al., 1997; Wajid et al., 2007). From the response of simulation modeling, it was found that the accuracy of simulated value decreases with delayed sowings for all varieties. Similar result was also reported by Pal et al. (2008).

Observed vs. simulated maximum leaf area index (LAI) and product harvest index (HI): It is evident from the data that maximum leaf area index ranged 3.3 to 4.8 and 1.4 to 2.3 for observed and simulated data, respectively, while, product harvest index ranged 0.43 to 0.46 for both observed and simulated data (Figs. 6 and 7).

The model underestimated the values of maximum LAI among sowing dates and varieties. Similar results have been reported by Kaur et al. (2007) and Wajid et al. (2007). The model failed to estimate the maximum LAI and the difference between simulated and observed values was large. LAI decreased with delayed sowing \{\%RMSE=59.9 (Nov. 20), 56.7 (Dec. 15) and 53.8 (Jan. 09)\}. Meza et al. (2008) reported reduction in leaf area index of maize crop with delayed sowings by using CERES-maize model.

In respect of HI the data of simulated and observed values are in close proximity to each other with crop sown on $20^{\text {th }}$ November $(\mathrm{t}=-3.9 ; \quad \% \mathrm{RMSE}=1.9)$ followed by rest of the sowing dates. The highest accuracy of predicted values over observed was accredited with the variety PBW-343 ( $\mathrm{t}=-0.3 ; \%$ $\mathrm{RMSE}=3.1) \quad$ than $\mathrm{WH}-542 \quad(\mathrm{t}=1.4 ; \quad \% \mathrm{RMSE}=5.0)$ [Table 2].

\section{Conclusion}

The results from this study showed an acceptable

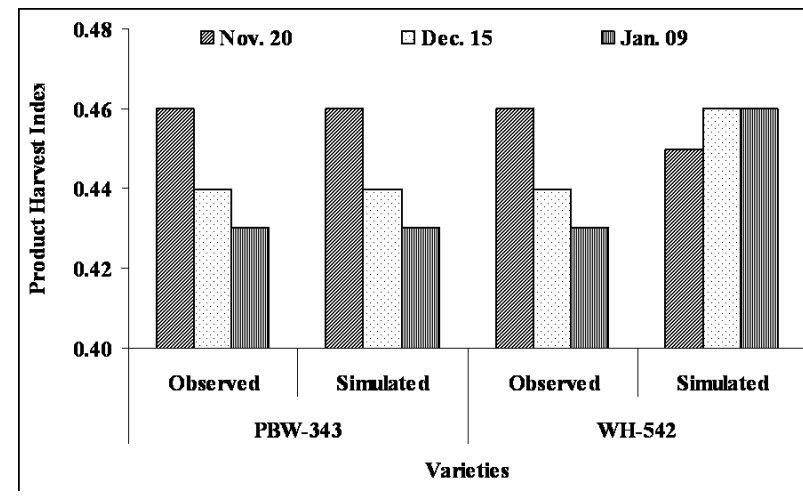

Fig. 7. Comparison between measured and simulated values for product Harvest Index at different dates of sowing and varieties of wheat (Mean of 2007-08 and 2008-09).

agreement between simulated and observed values for phonological events (except maximum leaf area index), total above ground dry biomass and grain yield of two wheat varieties for both model calibration and validation. The performance of CERES-wheat model was found better with crop sown on $20^{\text {th }}$ November than $15^{\text {th }}$ December and $09^{\text {th }}$ January during both crop growing seasons (2007-08 and 2008-09) for almost all the crop characters. Among crop components, simulated values were very close to the observed for the variety PBW-343 than WH-542. Therefore, $20^{\text {th }}$ November sowing date with the variety PBW-343 is recommended for foot hills of Western Himalayas region in order to obtain higher yield. CSM-CERES -Wheat has the potential in simulating development, growth and yield of wheat cultivars under various sowing dates, and this also indicated the possibility in using CSM-CERES-Wheat as a decision-supporting tool for wheat production in Western Himalayan regions.

\section{REFERENCES}

Andarzian, B., Bakhshandeh, A.M., Bannayan, M., Eman, Y., Fathia, G., Alami Saeed, K. (2008). WheatPot: a simple model for spring wheat yield potential using monthly weather data. Biosyst. Eng., 99: 487-495.

Bannayan, M., Crout, N.M.J. and Hoogenboom, G. (2003). Application of the CERES-Wheat model for within -season prediction of wheat yield in United Kingdom. Agron. J., 95: 114-125.

Bannayan, M., Kobayashi, K., Marashi, H. and Hoogenboom, G. (2007). Gene-based modeling for rice: an opportunity to enhance the simulation of rice growth and development ? J. Theor. Biol., 249: 593-605.

Bassu, S., Asseng, A., Motzo, R. and Giunta, F. (2009). Optimizing sowing date of durum wheat in a variable Mediterranean environment. Field Crops Res., 111: 109 -118 .

Datt, S., Shukla, S.N., Singh, S.S. and Shoran, J. (2009). Wheat: Many physiological traits have strong correlation with terminal heat tolerance. The Hindu Survey of Indian Agriculture, pp. 41-42.

Dhaliwal, L.K., Singh, G. and Mahi, G.S. (1997). Dynamic simulation of wheat growth, development and yield 
with CERES-wheat model. Annals of Agricultural Research, 18 (2): 157-164.

Department of Agriculture \& Co-operation (2012), Statewise Area, Production and Yield of Wheat for the year 2011 -12.http://www.agricoop.nic.in/imagedefault/trade/ wheat $\% 20$ profile.pdf

Ghaffari, A., Cook, H.F. and Lee, H.C. (2001). Simulating winter wheat yields under temperate conditions: exploring different management scenarios. Eur. J. Agron., 15: 231 -2440 .

Heng, L.K., Asseng, S., Mejahed, K. and Rusan, M. (2007). Optimizing wheat productivity in two rainfed environments of the west Asia-North Africa region using simulation model. Eur. J. Agron., 26: 121-129.

Heng, L.K., Baethegen, W.E. and Moutoonnet, P. (2000). The collection of a minimum data set and the application of DSSAT for optimizing wheat yield in irrigated cropping systems, pp. 7-17. In: Optimizing Nitrogen Fertilizer Application to Irrigated Wheat, IAEA TECDOC-1164, p. 245.

Hoogenboom, G., Jones, J.W., Wilkens, R.W., Batcheloro, W.D., Hunt, L.A., Boot, K.J., Singh, U., Uryasev, O., Bowen, W.T., Gijsman, A.J., du Toit, A., White, J.W. and Tsuji, G.Y. (2010). Decision support system for Agro-technology Transfer Version 4.5 [CD- ROM] University of Hawaii, Honolulu, HI.

Hundal, S.S. and Kaur, P. (1997). Application of the CERES -Wheat model to yield predictions in the irrigated plains of the Indian Punjab. J. Agric. Sci. Cambridge., 129: 13-18.

Jones, J.W., Hoogenboom, G., Porter, C.H., Boot, K.J., Batchelor, W.D., Hunts, L.A., Wilkens, P.W., Singh, U., Gijsman, A.J. and Ritchie, J.T. (2003). DSSAT cropping system model. Eur. J. Agron., 18: 235-265.

Kaur, M., Singh, K.N., Singh, H., Singh, P. and Tabasum, S. (2007). Evaluation of model CERES-wheat (v4.0) under temperate conditions of Kahmir Valley. World $J$. of Agril. Sci., 3(6): 825-832.

Kour, M., Singh, K.N., Singh, M., Thakur, N.P. and Kachroo, D. (2010). Phenophase prediction model for wheat (Triticum aestivum L.) growth using agrometeorological indices sown under different environments in temperate region of Kashmir. J. Agrometeorol., 12(1): 33-36.

Meza, F.J., Silva, D. and Vigil, H. (2008). Climate change impacts on irrigated maize in Mediterranean climates. Evaluation of double cropping as an emerging adaptation alternative. Agric Syst., 98: 21-30.

Mitchell, R.A.C. (1996). Predicting the effects of environmental change on winter wheat yield in genotypes with different flowering dates. Aspects of Applied Biology, 45: 133-138.

Nain, A.S. and Kersebaum, K.Ch. (2007). Calibration and validation of CERES-Wheat model for simulating water and nutrients in Germany K.Ch. Kersebaum (Ed.) et al., Modeling Water and Nutrient Dynamics in Soil-Crop -Systems, Springer, pp. 161-181.

Nain, A.S., Dadhwal V.K. and Singh T.P. (2002). Real time wheat yield assessment using technology trend and crop simulation model with minimal data set. Current Sci., 82(10): 1255-1258.

Ouda S.A., El-Marsafawy, S.M.; El-Kholy, M.A. and Gaballah, M.S. (2005). Simulating the effect of Water Stress and Different Sowing Dates on Wheat Production in South Delta. Journal of Applied Sciences Research 1: 268-276.

Pal, R.K., Murty, N.S. and M.M.N. Rao (2012). Evaluation of yield, dry matter accumulation and leaf area index in wheat (Triticum aestivum L.) genotypes as affected by different sowing environments. Environ. Ecol., 30 (4A): 1469-1473.

Pal, R.K., Rao, M.M.N. and Murty, N.S. (2013). Relative temperature disparity and wheat yield as influenced by sowing environments and genotypes in Tarai region of Uttarakhand. Environ. Ecol., 31 (2B): 979-983.

Pal, R.K., Tripathi, Padmakar and Mishra, A.K. (2008). Simulation modeling of growth parameters of wheat genotype using CERES-wheat model, J. Agrometeorol. (Special Issue-Part-I): 125-126.

Patel, H.R., Patel, G.G., Shroff, J.C., Pandey, V., Shekh, A.M., Vadodaria, R.P. and Bhatt, B.K. (2010). Calibration and validation of CERES-wheat model in middle Gujrat region. J. Agrometeorol., 12(1): 114-117.

Ritchie, J.T., Singh, U., Godwin, D.C. and Bowen, W.T. (1998). Cereal growth, development and yield G.Y. Tsuji, G. Hoogenboom, P.K. Thornton (Eds.), Understanding options for agricultural production, Kluwer Academic publishers, Dordrecht, The Netherland, pp. 79-98.

Sarkar, R. and Kar, S. (2006). Evaluation of management strategies for sustainable rice-wheat cropping system, using DSSAT seasonal analysis. J. Agr. Sci., 144:421-434

Timsina, J. and Humphreys, E. (2006). Performance of CERES-rice and CERES-Wheat models in rice-wheat systems: a review. Agric. Syst., 90: 5-31.

Timsina, J., Sigh, U., Singh, Y. and Lansigan, F.P. (1995). Addressing sustainability of RW systems: testing and applications of CERES and SUCROS models Proceedings of the International Rice Research Conference, 13-17 February 1995, IRRI, Los Banos, Philippines, pp. 663-656.

USDA (2014). Production, Supply, \& Distribution: Field Crops Production- Wheat Area, Yield, and Production at www.fas.usda.gov/psdonline, Date Created 04/09/2015.

Wajid, A., Hussain, K., Maqsood, M., Khaliq, T. and Ghaffari, A. (2007). Simulation modeling of growth, development and grain yield of wheat under semi arid conditions of Pakistan. Pak. J. Agri. Sci., 44(2): 194-199.

Zhang, X., Wang, S., Sun, H., Chen, S., Sho, L. and Liu, X. (2013). Contribution of cultivar, fertilizer and weather to yield variation of winter wheat over three decades: a case study in the North China Plain. Eur. J. Argon., 50: $52-59$ 